\title{
A NOVEL BIOCHEMICAL AND PHARMACOLOGICAL AGENT: L-AMINO ACID OXIDASE WITH CORRELATION TO CANCER MANAGEMENT: AN OVERVIEW
}

\author{
Sanjesh Kumar ${ }^{*}$, A. Nath ${ }^{2}$, KrishnaMurti ${ }^{1}$, Manoj Kumar Sethi ${ }^{1}$, \\ MD Tarique Nadeem ${ }^{1}$, P. Das ${ }^{3}$. \\ ${ }^{I}$ Department of Pharmacy Practice, National Institute of Pharmaceutical Education \& Research, Hajipur, India. \\ ${ }^{2}$ Department of Cancer research, Mahavir Cancer Institute \& Research Centre, Patna,India. \\ ${ }^{3}$ Department of Molecular Biology, Rajendra Memorial Research Institute of Medical Sciences, Patna, India.
}

\begin{abstract}
Different types of snake venom including LAAO venom found in different organism which possesses anticancer effect as well as other pharmacological activity. Now a days using medicine for cancer treatment that have a lots of adverse effect such as alopecia, bone marrow depression, vomiting etc., we are focusing on SV-LAAOs to search out the natural bioactive novel agents. King cobra venom LAAO has more stability than other SV-LAAOS which may be correct agent to developed anticancer medicine. These effects mainly produced due to hydrogen peroxide which is generated during catalytic reaction.
\end{abstract}

KEYWORDS: L-amino acid oxidase, cancer, snake venom, $\mathrm{H}_{2} \mathrm{O}_{2}$, cytotoxic effect.

\section{INTRODUCTION}

Snake venom is a complex mixture of different components that include peptides, proteins, enzymes, carbohydrates, and minerals [1]. L-amino acid oxidases (LAAOs) are widely distributed in many different species including insects, fungi, bacteria, and snakes [2] and are found even in plants where one of their catalytic products, ammonia, is used as a nitrogen source in cell metabolism [3, 4]. Experiments have shown that cytotoxic effects displayed by snake venoms are specifically related to the species, genus, and tissue targets. Thus, these findings provide new direction and probable application of snake venom as well as isolated toxins for cancer treatment [5]. L-Amino acid oxidase (L-amino acid:O2 oxidoreductase, E.C. 1.4.3.2.) is a flavoenzyme that catalyzes the oxidative deamination of an L-amino acid to form the corresponding $\alpha$-ketoacid, hydrogen peroxide and ammonia. The detailed chemical equation of the mentioned reaction is shown below:

$$
\mathrm{R}-\mathrm{CHNH}_{2}-\mathrm{COOH}\left(\mathrm{L} \text {-amino acid) }+\mathrm{O}_{2}+\mathrm{H}_{2} \mathrm{O} \stackrel{\text { L-AAO }}{\longrightarrow} \mathrm{R}-\mathrm{CO}-\mathrm{COOH} \text { (a-keto acid) }+\mathrm{NH}_{3}+\mathrm{H}_{2} \mathrm{O}_{2}\right.
$$

L-Amino acid oxidase (LAAO) occurs widely in nature [6] and snake venoms are perhaps the richest sources of the enzyme. Snake venom LAAOs are generally very active and have been used widely in preparation of $\alpha$-keto acids because of their chemo- and stereospecificity[7,8]. It represents 1-9\% of total venom protein [2]. Almost all LAAOs described to date are flavoproteins of dimeric structure, with each subunit presenting a non-covalent bond with flavin mononucleotide (FMN) or flavin adenine dinucleotide (FAD). Flavins present in LAAOs are responsible for the characteristic yellow color of many snake venoms and contribute to their toxicity because of the oxidative stress that results from the production of $\mathrm{H}_{2} \mathrm{O}_{2}[9]$. Recently, snake venom LAAO has become an interesting object for biomedical studies because of its antimicrobial, anti-HIV, anticoagulant, platelet aggregation-inducing and inhibiting, apoptotic-inducing as well as anti-cancer activities. Snake venom LAAO is recognized as a multifunctional protein with promising biomedical application. Several reviews on snake venom L-amino acid oxidases have been published in many journals. [2, 6, 10-14]. The individual LAAOs differ in their substrate specificity: snake venom L-amino acid oxidases (SV-LAAOs) which constitute upto 30\% (by weight) of the crude venom, possess a clear preference for hydrophobic amino acids [15].

The king cobra (Ophiophagus hannah) venom LAAO, with a molecular weight of $130 \mathrm{kDa}$, has an unusual thermal stability which is different from other venom LAAOs. At $\mathrm{pH} 7.4$, the enzyme retained $100 \%$ activity after incubation at $37^{\circ} \mathrm{C}$ for 5 days. Unlike other snake venom LAAO, king cobra venom LAAO was stable at alkaline condition and was not inactivated by freezing [16]. Because of these favourable stability properties, king cobra venom LAAO has a greater potential, when compared to other venom LAAOs, to be 
developed as a cancer therapeutic agent. Earlier studies also showed that the king cobra venom enzyme exhibited extremely potent anti-proliferative activities in comparison with other venom LAAOs, and that its cytotoxicity was selective against tumorigenic cells [17]. Nowadays, treatment of cancer is a major challenge to the medical world. Present methods of treatment are very costly and have numerous side effects. Patient has to suffer physically, mentally as well as economically. Some of the components of snake venom cause retardation of growth of cancerous cells. Due to its therapeutic activity, potency and availability, snake venom may be a vital nominee for the medicine in the future for many diseases and disorders [18]. Snake venoms are recognized as useful sources of bioactive substances showing a wide range of biochemical \& pharmacological activities. The purpose of this article is to review recent finding regarding therapeutic potential of snake venom L-amino acid oxidase with correlation to cancer management.

\section{A POTENT BIOCHEMICAL ANALOGUE}

Many studies have been described that the SV-LAAOs are a potent biochemical analogue showing different biological activities such as edematogenic, hemorrhagic, anticoagulant, platelet aggregation inducing and inhibiting activities. Hydrogen peroxide not alone is responsible for these biological activities of SVLAAOs; that is, other mechanisms are probably triggered and cause a potent biological response [19]. Some studies have been conducted to determine the true mode of action of LAAOs in the induction of edema, that revealed that the action of these compounds is related to the stimulation and release of inflammatory mediators such as histamine, prostaglandin, kinins, and serotonin [25]. The edematogenic activity of LAAOs enzymes do not lose their activity in the presence of antihistamines but the activity of this enzyme was completely suppressed when treated with glutathione, indicating that edema induced by LAAO is directly related to the presence of hydrogen peroxide. The hemorrhagic induction of snake venoms mediated by degradation of extracellular matrix proteins of vascular endothelium. Souza et al. [20] proposed that SV-LAAOs trigger a process of apoptosis in vascular endothelial cells, causing rupture of the endothelium and concomitant leakage of blood to the interstice. SV-LAAO purified from Agkistrodon halys blomhoffii venom possesses anticoagulant activity [21].The enzyme significantly delayed the onset and progress of blood coagulation, prolonged the activated partial thromboplastin time but had little effect on the prothrombin time. It is interferes primarily with the intrinsic blood coagulation pathway, and further studies indicated that the anticoagulant effect of LAAO is due to its inhibitory action on clotting factor IX. SV-LAAOs activities on platelets is still controversial, with a variable potential of these enzymes to inhibit or induce platelet aggregation. Some investigation reported that LAAOs induce platelet aggregation, whereas others reported that LAAOs have an inhibitory action on platelet aggregation [2]. Catalase, a $\mathrm{H} 2 \mathrm{O} 2$ scavenger, inhibited both platelet aggregation inducing and inhibiting effects, indicating that both effects are due primarily to the action of $\mathrm{H} 2 \mathrm{O} 2$ produced by the enzyme during the oxidation. LAAOs from venoms of C. Durissus cascavella, E. macmahoni, B. alternatus, B. pirajai, O. hannah induce platelet aggregation [22-26]. On the other hand, LAAOs from A. h. blomhoffi, V. lebetina and N. naja kaouthia dose-dependently inhibited both agonist-induced platelet aggregation and shear induced platelet aggregation [27-29]. LAAO isolated from Ophiophagus hannah dose dependently, induces platelet aggregation in the concentration range of $10-60 \mathrm{mg} / \mathrm{ml}$, and inhibit platelet aggregation in the concentration range of 4.8-48 $\mathrm{mg} / \mathrm{ml}(\mathrm{IC} 500.15 \mathrm{mM})[30]$.

\section{A POTENT PHARMACOLOGICAL AGENT}

SV-LAAOs is a potent pharmacological agent have become an interesting object for biomedical studies because of its bactericidal, leishmanicidal, antiviral, apoptotic, cytotoxic, and other physiological effects. These effects are mediated by the chemically very reactive hydrogen peroxide generated in the oxidation process, because $\mathrm{H} 2 \mathrm{O} 2$ scavenger such as catalase neutralizes the effects. Sometimes the toxic effects cannot be attributed to $\mathrm{H} 2 \mathrm{O} 2$ liberated alone and direct interactions between LAAO and the target cells may play an important role [31]. The antibacterial property of snake venom, in particular, has gathered increasing scientific interest due to antibiotic resistance. Infections of microorganism may be difficult to treat due to developing resistance to the current available antimicrobial agents. Examples of bacterial species that have developed resistance to conventional antibiotics are Pseudomonas, Klebsiella, Enterobacter, Acinetobacter, Mycobacterium, Salmonella, Staphylococcus, Enterococcus and Streptococcus [32, 33]. Therefore, we are searching new biochemical sources for the development of novel antimicrobial agents. King cobra venom was most efficient against Escherichia coli and was least effective against Pseudomonas aeruginosa [34]. A recent study describe that the minimum inhibitory concentrations (MIC)of the Siamese Russell's viper LAAO enzyme against Staphylococcus aureus ATCC 25923, Pseudomonas aeruginosa ATCC 27853 and Escherichia coli ATCC 25922 higher than the MIC of king cobra LAAO [19]. It is also shown antiviral effect which has been well explored. Zhang et al. reports the possible inhibition of HIV-1 infection and replication by an LAAO isolated from Trimeresurus stejnegeri venom, called TSVLAO [31]. This activity was mediated by a reduction in a protein p24 production as well as decrease in syncytium formation. The antiviral potential of LAAOs was 
also studied against DENV-3 virus strains, the etiological agent of dengue, with BjarLAAOI isolated from Bothrops jararaca snake venom [35]. The treatment's efficiency was demonstrated due to reduction of viral load in previously infected C6/36 cells exposed to the toxin when compared to controls of unexposed infected cells. SV-LAAOs are also possesses Leishmanicidal activity [26, 36], as the $\mathrm{H} 2 \mathrm{O} 2$ generated by the enzyme was a strong inducer of apoptosis in promastigotes of Leishmania ssp. cells. The first-line drugs for the treatment of Leishmaniasis are pentavalent antimonials, which have serious side effects and to which the target parasites have shown clinical resistance. Thus, the study of new Leishmanicidal compounds from different sources, including those with antileishmanial activity, is needed for drugs development. An LAAO isolated from $B$. moojeni venom showed leishmanicidal activity against promastigote forms of Leishmania amazonensis five times higher than that of the crude venom [37, 38].

\section{RECENT UPDATE ON CANCER MANAGEMENT}

Cancer is characterized by uncontrolled cell division, cell transformation, and escape of apoptosis, invasion, angiogenesis and metastasis [39]. The anti-cancer property of snake venom, in particular, has gathered increasing scientific interest due to its potential natural-based cancer therapeutic agents that exhibit highly selective cytotoxicity against cancer cells over the normal cells. Recently ML. Lee et al. [40] reported that LAAO isolated from king cobra venom Induces Apoptosis in prostate adenocarcinoma (PC-3) Cells and Suppresses PC-3 Solid Tumor Growth in a Tumor Xenograft Mouse Model but did not shows any abnormality on the normal organ tissue. Previously discussed that the king cobra venom (LAAO) enzyme also exhibited extremely potent anti-proliferative activities in comparison with other venom LAAOs, and that its cytotoxicity was selective against tumorigenic cells (breast cancer and lung cancer cells) [17]. The cytotoxic effect of SVLAAOs on normal cells is still controversial, some of groups suggesting it is harmless to normal cells while other mentioning its having cytotoxic effect on normal cells. A large number of studies demonstrated the invitro anti-cancer action but very few studies that demonstrated the in vivo anti-cancer action of snake venom LAAOs on tumors. Induction of apoptosis is the most important mechanism of many anticancer agents. Many research groups describe LAAOs as apoptosis inducers, in human embryonic cells (293T) [41], human promyelocytic leukemia cells (HL-60) [42, 43], human monocytic cells (MM6) [48], rat lymphocytic leukemia cells (L1210), and human leukemia T cells [25]. Apoptosis is an important pathway of LAAOs of exerting cytotoxicity activity selectively against cancer cells, it is reported many previous reports [37, 43-47]. Several of the LAAOs isolated have been considered cytotoxic, including APIT to Jurkat T cells [48], Vipera berus berus LAAO to HeLa and K562 cells [49], BpirLAAOI to S180 cells and macrophages [50], ABU-LAO to human monocytes and T cells [43], BmooLAAO-I to Ehrlich ascites tumor cells [23], BatroxLAAO to HL-60, Jurkat, B16F10, and PC12 cells [49], ACTX-8 to HeLa cells [37], BjarLAAO-I to Ehrlich ascites tumour [45], BFLAAO to A549 cells [35], BpLAAO to SKBR3 breast carcinoma and Jurkat leukemia cells [49], BmarLAAO to macrophages [51], Bl-LAAO to LL- 24, RKO, HUTU, and MKN-45 cells [52], and LmLAAO to AGS cellsgastric adenocarcinoma and MCF-7 cells-breast adenocarcinoma [53]. Cura et al. [54] reported that Ophiophagus hannah LAAO venom decreases thymidine uptake in fibrosarcoma, colorectal cancer and Chinese hamster ovary cell line as well as also showed reduction in cellular proliferation. Also, LAAO isolated from Agkistrodon acutus snake venom showed accumulation of tumor cell at sub-G1 phase of cell cycle and induced apoptosis via Fas pathway in A549 cells (human alveolar epithelial cell line) [55]. Ande et al. [56] and Samel et al. [57], using Jurkat and K562 (human chronic myeloid leukemia) cells, respectively, reported that at low concentration LAAO induced apoptosis, but caused necrosis at higher concentrations of LAAO. The factors contributing to apoptosis are: (i) generation of toxic intermediates from fetal calf serum and (ii) binding and internalization of LAAO, which appears to be mediated by the glycan moiety of the enzyme, as desialylation of the enzyme reduces cytotoxicity [56]. In 1999, Souza et al. [58] showed the cytotoxicity level of an LAAO from Agkistrodon contortrix laticinctus through the fragmentation of DNA onHL-60 cultures hybrid cells. We can say that SV-LAAOs isolated from different snakes species showing antitumor effect at a different concentration by different mechanism. Different concentration and treatment time were obtained through several assays regarding their cytotoxic effect upon cell cultures and animal models, as well as the mechanisms involved and reactions able to explain these effects are given in the table1. 
Table -1 showing various LAAOs venom and their effect.

\begin{tabular}{|c|c|c|c|c|}
\hline $\begin{array}{c}\text { LAAOs } \\
\text { Venom } \\
\text { Protein } \\
\text { name }\end{array}$ & Snakes & $\begin{array}{c}\text { Cellular } \\
\text { target/mechanism }\end{array}$ & $\begin{array}{l}\text { Concentration and } \\
\text { treatment time }\end{array}$ & reference \\
\hline LAAO & $\begin{array}{l}\text { Ophiophagus } \\
\text { hannah }\end{array}$ & $\begin{array}{l}\text { Demonstrated potent cytotoxicity against } \\
\text { PC-3, stomach cancer, murine melanoma, } \\
\text { fibrosarcoma, and colorectal and ovary cell } \\
\text { lines. }\end{array}$ & $\begin{array}{l}0.05-2 \mu \mathrm{g} / \mathrm{mL} \text { for } 72 \\
\mathrm{~h}\end{array}$ & {$[40,59]$} \\
\hline B1-LAAO & $\begin{array}{l}\text { Bothrops } \\
\text { leucurus }\end{array}$ & $\begin{array}{l}\text { Cytotoxicity in the stomach cancer MKN- } \\
45 \text {, adenocarcinoma HUTU, colorectal } \\
\text { RKO, and human fibroblast LL- } 24 \text { cell } \\
\text { lines. }\end{array}$ & $\begin{array}{l}0.1-20 \mu \mathrm{g} / \mathrm{mL} \text { for } 24 \\
\mathrm{~h}\end{array}$ & [54] \\
\hline ACTX-8 & $\begin{array}{l}\text { Agkistrodon } \\
\text { acutus }\end{array}$ & $\begin{array}{l}\text { Induces apoptosis in human cervical cancer } \\
\text { Hela cell line. }\end{array}$ & $\begin{array}{l}20 \mu \mathrm{g} / \mathrm{mL} \text { for } 12-48 \\
\mathrm{~h}\end{array}$ & [49] \\
\hline $\begin{array}{l}\text { BmooLAAO } \\
\text {-I }\end{array}$ & Bothrops moojeni & Cytotoxicity and apoptosis & $8-16 \mu \mathrm{g} / \mathrm{mL}$ for $12 \mathrm{~h}$ & [60] \\
\hline LAAO & $\begin{array}{l}\text { Vipera berus } \\
\text { berus }\end{array}$ & $\begin{array}{l}\text { Induces apoptosis in } \mathrm{HeLa} \text { and } \mathrm{K} 562 \text { cell } \\
\text { lines. }\end{array}$ & $\begin{array}{l}2.5-10 \mu \mathrm{g} / \mathrm{mL} \text { for } 7- \\
24 \mathrm{~h}\end{array}$ & [43] \\
\hline LAAO & $\begin{array}{l}\text { Trimeresurus } \\
\text { flavoviridis }\end{array}$ & Antitumor activity in RBR17T and C6 cell & $\begin{array}{l}2.5 \text { and } 5 \mu \mathrm{g} / \mathrm{mL} \text { for } \\
24 \mathrm{~h}\end{array}$ & [47] \\
\hline LAAO & $\begin{array}{l}\text { Eristicophis } \\
\text { macmahoni }\end{array}$ & Apoptosis & $\begin{array}{l}25-100 \mu \mathrm{g} / \mathrm{mL} \text { for } 18 \\
\mathrm{~h}\end{array}$ & [26] \\
\hline LAAO & $\begin{array}{l}\text { Agkistrodon } \\
\text { contortrix } \\
\text { laticinctus }\end{array}$ & Caused DNA fragmentation in HL-60 cells. & $\begin{array}{l}2.5-100 \mu \mathrm{g} / \mathrm{mL} \text { for } \\
16 \mathrm{~h}\end{array}$ & [20] \\
\hline LmLAAO & Lachesis muta & $\begin{array}{l}\text { Cytotoxicity in the LL-24, AGS, } \\
\text { MCF-7, and HUTU }\end{array}$ & $\begin{array}{l}1.17-75 \mu \mathrm{g} / \mathrm{mL} \text { for } \\
24 \mathrm{~h}\end{array}$ & [55] \\
\hline
\end{tabular}

\section{CONCLUSION AND FUTURE PROSPECTS}

Many experiments have shown that cytotoxic effects displayed by snake venoms LAAOs are specifically related to the species, genus, and tissue targets for cancer treatment. SV-LAAOs is a flavoenzyme that catalyzes the oxidative deamination of an L-amino acid to form the corresponding $\alpha$-ketoacid, hydrogen peroxide and ammonia. A lots of biomedical studied described that snake venom LAAOs as an interesting object because of its antimicrobial, anti-HIV, leishmanicidal, anticoagulant, platelet aggregation-inducing and inhibiting, apoptotic-inducing as well as anti-cancer activities. All these above pharmacological effect are produce mainly by hydrogen peroxide which is produce during catalytic oxidative reaction of LAAOs.

Unlike other venom LAAOs, king cobra (Ophiophagus hannah) venom LAAO has an unusual stability as well as selective cytotoxicity against tumorgenic cells. Because of these favourable stability properties, king cobra venom LAAO has a greater potential, when compared to other venom LAAOs, to be developed as a cancer therapeutic agent. SV-LAAOs which isolated from different species of snakes are effective against different cancer cell lines both in-vitro as well as in-vivo condition at different concentration. The effect of SV-LAAOs only check out against cancer cell lines but do not check out against chemical induced cancer. So snake venom LAAOs may be open the doors to investigate against chemical induced cancer. Some SV-LAAOs also effective against viruses. So these venom may be a future prospect for the treatment of Ebola virus because no one's check out the effect against Ebola virus. These venom open a gate to check out the effect of SV-LAAOs against Ebola virus.

CONFLICTS OF INTERESTS The authors hereby declare that there is no conflict of interests.

\section{ACKNOWLEDGEMENT}

The author would like to thank Department of Pharmacy Practice, National Institute of Pharmaceutical Education \& Research, Hajipur, India, Mahavir Cancer Institute \& Research Centre, Patna, India, and Rajendra Memorial Research Institute of Medical Sciences, Patna, India. 


\section{REFERENCES}

[1]. J. J. Calvete et al. "Snake venomics. Strategy and applications," Journal of Mass Spectrometry, vol. 42, no. 11, pp. 1405-1414, 2007.

[2]. X.-Y.Du and K. J. Clemetson, "Snake venomL-amino acid oxidases," Toxicon, vol. 40, no. 6, pp. 659-665, 2002.

[3]. T. Nishizawa, C. C. Aldrich, and D. H. Sherman, "Molecular analysis of the rebeccamycin L-amino acid oxidase from Lechevalieria aerocolonigenes ATCC 39243,” Journal of Bacteriology, vol. 187, no. 6, pp. 2084-2092, 2005.

[4]. J. T. Nuutinen and S. Timonen, "Identification of nitrogen mineralization enzymes, 1-amino acid oxidases, from the ectomycorrhizal fungi Hebeloma spp. and Laccaria bicolor," Mycological Research, vol. 112, no. 12, pp. 1453-1464, 2008.

[5]. G. Borkow et al. "Binding of cytotoxin P4 from Naja nigricollis nigricollis to B16F10 melanoma and WEHI-3B leukemia cells," FEMS Microbiology Immunology, vol. 5, no. 1-3, pp. 139-146, 1992.

[6]. S. Iwanaga , T. Suzuki. L-Amino acid oxidase. In: Lee CY ed. Handbook of experimental pharmacology. Berlin: Springer.vol. 52. pp. 75-84. 1979.

[7]. $\quad$ E. Szwajcer, P. Brodelius, K. Mosbach. Production of $\square$-keto acids. Part 2: Immobilized whole cells of Providencia sp. PCM 1298 containing L-amino acid oxidase. Enzyme Microb Technol; vol. 4 pp. 409-413. 1982.

[8]. Z. Findrik, B. Geueke, W. Hummel, D. Vasic-Racki. Modelling of L-DOPA enzymatic oxidation catalyzed by L-amino acid oxidase from Crotalus adamanteus and Rhodococcus opacus. Biochem Eng J; vol. 27 pp. 275-286. 2006

[9]. C. Guo, S. Liu, Y. Yao, Q. Zhang, MZ. Sun: Past decade study of snake venom L-amino acid oxidase. Toxicon, 60(3). pp. 302311. 2012.

[10]. A. Meister, D. Wellner. Flavoprotein amino acid oxidases. In: Boyer PD, Lardy H, Myrback K eds. The enzymes, $2^{\text {nd }}$ Ed. New York: Academic Press; Vol. VII: pp.609-648 1963.

[11]. DJ. Bright, DJT. Porter. Flavoprotein oxidases. In: Boyer PD ed. The enzymes 3rd Ed. New York: Academic Press Vol. XIIB. pp 421-505. 1975.

[12]. AT. Tu. Venoms: Chemistry and molecular biology. New York: John Wiley, pp. 459-483, 1977.

[13]. B. Curti, V. Massey, M. Zmudha. Inactivation of snake venom L-amino acid oxidase by freezing. J Biol Chem; vol. 243. pp. 2306-2314. 1968

[14]. NH. Tan. L-Amino acid oxidases and lactate dehydrogenases. In: Bailey GS ed. Enzymes from snake venom. Fort Collins: Alaken Inc. Chapter 19, pp. 579-598. 1998;

[15]. G. Ponnudurai, MC. Chung, NH. Tan. Purification and properties of the L-amino acid oxidase from Malayan pit viper (Calloselasma rhodostoma) venom. Arch. Biochem. Biophys.; vol. 313: pp. 373-378. 1994.

[16]. NH. Tan, MN. Saifuddin. Isolation and characterization of an unusual form of Lamino acid oxidase from cobra (Ophiophagus hannah) venom. Biochem Int.vol. 19: pp. 937-944. 1989.

[17]. ML. Lee, I. Chung, SY. Fung, MS. Kanthimathi, NH. Tan. Anti-proliferative activity of king cobra (Ophiophagus Hannah) venom L-amino acid oxidase. Basic and Clinical Pharmacology and Toxicology. DOI: 10.1111/bcpt.12155. 2013

[18]. KM. Debatin, P. Krammerr. Death receptors in chemotherapy and cancer. Oncogene. Vol. 23: pp. $2950-2966.2004$.

[19]. S.-R. Zhong, Y. Jin, J.-B. Wu et al., "Purification and characterization of a new 1-amino acid oxidase from Daboia russellii siamensis venom," Toxicon, vol. 54, no. 6, pp. 763-771, 2009.

[20]. D. H. F. Souza, L. M. Eugenio, J. E. Fletcher et al., "Isolation and structural characterization of a cytotoxic L-amino acid oxidase from Agkistrodon contortrix laticinctus snake venom: preliminary crystallographic data," Archives of Biochemistry and Biophysics, vol. 368, no. 2, pp. 285-290, 1999.

[21]. Y. Sakurai, M. Shima, T. Matsumoto, H. Takatsuka, K. Nishiya, S. Kasuda, Y. Fujimura, A. Yoshioka. Anticoagulant activity of M-LAO, L-amino acid oxidase purified from Agkistrodon halys blomhoffii, through selective inhibition of factor IX. Biochem Biophys Acta; vol. 1649: pp. 51-57. 2003

[22]. RG. Stabeli, S. Marcussi, GB. Carlos, RCLR. Pietro, HS. Selistrede-Araujo, JR. Giglio, EB. Oliveira, AM. Soares. Platelet aggregation and antibacterial effects of an L-amino acid oxidase purified from Bothrops alternatus snake venom. Bioorg Med Chem; vol. 12: pp. 2881-2886. 2004.

[23]. L.F.M. Izidoro,M. C. Ribeiro,G. R. L. Souza et al., "Biochemical and functional characterization of an 1-amino acid oxidase isolated from Bothrops pirajai snake venom," Bioorganic and Medicinal Chemistry, vol. 14, no. 20, pp. 7034-7043, 2006.

[24]. ZY. Li, TF. Yu, EC. Lian. Purification and characterization of L-amino acid oxidase from king cobra (Ophiophagus hannah) venom and its effects on human platelet aggregation. Toxicon; vol. 32: pp. 1349-1358. 1994.

[25]. S. A. Ali, S. Stoeva, A. Abbasi et al., "Isolation, structural, and functional characterization of an apoptosis-inducing L-amino acid oxidase from leaf-nosed viper (Eristocophis macmahoni) snake venom," Archives of Biochemistry and Biophysics, vol. 384, no. 2, pp. 216-226, 2000.

[26]. MH. Toyama, D de O. Toyama, LFD. Passero, MD. Laurenti, CE. Corbett, TY. Tomokane, FV. Fonseca, E. Antunes, PP. Joazeiro, LOS. Beriam, MAC. Martins, HAS. Monteiro, MC. Fonteles. Isolation of a new L-amino acid oxidase from Crotalus durissus cascavella venom. Toxicon; vol. 47: pp. 47-57. 2006.

[27]. H. Takatsuka, Y. Sakurai, A. Yoshioka, T. Kokubo, Y. Usami, M. Suzuki, T. Matsui, K. Titani, H. Yagi, M. Matsumoto, Y. Fujimura. Molecular characterization of L-amino acid oxidase from Agkistrodon halys blomhoffii with special reference to platelet aggregation. Biochim Biophys Acta; vol. 1544: pp. 267-277. 2001.

[28]. K. Tonismagi, M. Samel, K. Trummal, G. Ronnholm, J. Sugiir, N. Kalkkinen, E. Sugiir. L-Amino acid oxidase from Vipera lebetina venom: Isolation, characterization, effects on platelets and bacteria. Toxicon; vol. 48: pp. 227-237. 2006.

[29]. Y. Sakurai, H. Takatsuka, A. Yoshioka, T. Matsui, M. Suzuki, K. Titani, Y. Fujimura. Inhibition of human platelet aggregation by L-amino acid oxidase purified from Naja naja kaouthia venom. Toxicon; pp. 39: pp. 1827-1833. 2001.

[30]. Y. Jin, WH. Lee, L. Zeng, Y. Zhang. Molecular characterization of L-amino acid oxidase from king cobra venom. Toxicon. Vol. 50: pp. 479-489. 2007.

[31]. YI. Zhang, JH.Wang, WH. Lee, Q. Wang, H. Liu, YT. Zheng, Y. Zhang. Molecular characterization of Trimeresurus stejnegeri venom L-amino acid oxidase with potential anti-HIV activity. Biochim Biophys Res Commum; vol. 309: pp. 598-604. 2003. JY. Ang, E. Ezike, BI. Asmar. Antibacterial resistance. Indian J Pediatr; 71(3): pp.229-39. 2004.

[32]. JY. Ang, E. Ezike, BI. Asmar. Antibacterial resistance. Indian J Pediatr; 71(3): pp.229-39. 2004.
[33]. TM. Barbosa, SB. Levy. The impact of antibiotic use on resistance development and persistence. Drug Resist Updat.;3(5): pp. 303-11. 2000.

[34]. CS. Phua' J. Vejayan' S. Ambu' G. Ponnudurai' A. Gorajana Purification and antibacterial activities of an L-amino acid oxidase from king cobra (Ophiophagus hannah) venom. J. Venom. Anim. Toxins incl. Trop. Dis vol.18 no.2 Botucatu 2012. 
[35]. C.D. Sant'Ana, D. L. Menaldo, T. R. Costa et al., "Antiviral and antiparasite properties of an 1-amino acid oxidase from the Snake Bothrops jararaca: cloning and identification of a complete cDNA sequence," Biochemical Pharmacology, vol. 76, no. 2, pp. 279-288, 2008 .

[36]. BG. Stiles, FW. Sexton, SA. Weinstein. Antibacterial effect in different snake venoms: purification and characterization of antibacterial protein from Pseudochis australis (Australian king or mulga snake) venom. Toxicon; vol. 29: pp. 1129-1141. 1991.

[37]. R. G. St'abeli, C. D. Sant'Ana, P. H. Ribeiro et al., "Cytotoxic Lamino acid oxidase from Bothrops moojeni: biochemical and functional characterization," International Journal of Biological Macromolecules, vol. 41, pp. 132-140, 2007.

[38]. R. Fernandez-Gomez, H. Zerrouk, F. Sebti, M. Loyens, A. Benslimane, and M. Ali Ouaissi, "Growth inhibition of Trypanosoma cruzi and Leishmania donovani infantumby different snake venoms: preliminary identification of proteins from Cerastes cerastes venom which interact with the parasites," Toxicon, vol. 32, no. 8, pp. 875-882, 1994.

[39]. CY. Koh, RM. Kini. From snake venom toxins to therapeutics -Cardiovascular examples. Toxicon; vol. 59: pp. 497-506. 2012.

[40]. ML. Lee, SY. Fung, I. Chung, J. pailoor, SH. Cheah, NH. Tan, "King Cobra (Ophiophagus hannah) Venom L-Amino Acid Oxidase Induces Apoptosis in PC-3 Cells and Suppresses PC-3 Solid Tumor Growth in a Tumor Xenograft Mouse Model,” Int. J Med Sci.; 11(6): 593-601. 2014.

[41]. S. Torii, M. Naito, and T. Tsuruo, “Apoxin I, a novel apoptosisinducing factor with L-amino acid oxidase activity purified from western diamondback rattlesnake venom," Biochemistry, vol. 39, pp. 3197-3205, 2000.

[42]. S. Torii, M. Naito, and T. Tsuruo, "Apoxin I, a novel apoptosisinducing factor with L-amino acid oxidase activity purified from western diamondback rattlesnake venom," The Journal of Biological Chemistry, vol. 272, no. 14, pp. 9539-9542, 1997.

[43]. M. Samel, H. Vija, G. R"onnholm, J. Siigur, N. Kalkkinen, and E. Siigur, "Isolation and characterization of an apoptotic and platelet aggregation inhibiting 1-amino acid oxidase from Vipera berus berus (common viper) venom," Biochimica et Biophysica Acta, vol. 1764, no. 4, pp. 707-714, 2006.

[44]. S. Suhr and D. Kim, "Identification of the snake venom substance that induces apoptosis," Biochemical and Biophysical Research Communications, vol. 224, no. 1, pp. 134-139, 1996.

[45] . R. M. Alves, G. A. Antonucci, H. H. Paiva et al., "Evidence of caspase-mediated apoptosis induced by 1-amino acid oxidase isolated from Bothrops atrox snake venom," Comparative Biochemistry and Physiology, vol. 151, no. 4, pp. 542-550, 2008.

[46]. MR. Alves, RF .Figueiredo, GA. Antonucci, HH. Paiva, LB. Pires. et al. Cell cycle arrest evidence, parasiticidal and bactericidal properties induced by L-amino acid oxidase from Bothrops atrox snake venom. Biochemie.vol. 93: pp. 941-947. 2011.

[47]. LK. Sun, Y. Yoshii, A. Hyodo, H. Tsurushima, A. Saito. et al. Apoptotic effect in the glioma cells induced by specific protein extracted from Okinawa Habu (Trimeresurus flavoviridis) venom in relation to oxidative stress.Toxicol in vitro. Vol. 17: pp. 169-177. 2003

[48]. L. Zhang, L. Cui. A cytotoxin isolated from Agkistrodon acutus snake venom induces apoptosis via Fas pathway in A549 cells. Toxicol in vitro. Vol. 21: pp. 1095-1103. 2007.

[49]. L. Zhang and L.-J. Wei, "ACTX-8, a cytotoxic 1-amino acid oxidase isolated fromAgkistrodon acutus snake venom, induces apoptosis in Hela cervical cancer cells," Life Sciences, vol. 80, no. 13, pp. 1189-1197, 2007.

[50]. D. Butzke, R. Hurwitz, B. Thiede, S. Goedert, and T. Rudel, "Cloning and biochemical characterization of APIT, a new Lamino acid oxidase fromAplysia punctata," Toxicon, vol. 46, no. 5, pp. 479-489, 2005.

[51]. J.-F.Wei, H.-W. Yang, X.-L.Wei, L.-Y.Qiao,W.-Y.Wang, and S.- H.He, "Purification, characterization and biological activities of the 1-amino acid oxidase fromBungarus fasciatus snake venom," Toxicon, vol. 54, no. 3, pp. 262-271, 2009.

[52]. R. S. Rodrigues, J. F. da Silva, J. Boldrini Franc, a et al., "Structural and functional properties of Bp-LAAO, a new 1-amino acid oxidase isolated fromBothrops pauloensis snake venom," Biochimie, vol. 91, no. 4, pp. 490-501, 2009.

[53]. A. F. Costa Torres, R. T. Dantas, M. H. Toyama et al., "Antibacterial and antiparasitic effects of Bothrops marajoensis venom and its fractions: phospholipase A2 and 1-amino acid oxidase," Toxicon, vol. 55, no. 4, pp. 795-804, 2010.

[54]. G. B.Naumann, L. F. Silva, L. Silva et al., "Cytotoxicity and inhibition of platelet aggregation caused by an 1-amino acid oxidase from Bothrops leucurus venom," Biochimica et Biophysica Acta, vol. 1810, no. 7, pp. 683-694, 2011.

[55]. C. Bregge-Silva,M. C.Nonato, S. Albuquerque et al., "Isolation and biochemical, functional and structural characterization of a novel L-amino acid oxidase from Lachesismuta snake venom," Toxicon, vol. 60, pp. 1263-1276, 2012.

[56]. JE. Cura, DP. Blanzaco, C. Brisson, et al. Phase I and pharmacokinetics study of crotoxin (Cytotoxic PLA2, NSC- 624244) in Patients with advanced cancer. Clin Cancer Res, 8, 1033-41, 2002.

[57]. IC. Kang, YD. Lee, DS. Kim. A novel disintegrin salmosin inhibits tumor angiogenesis. Cancer Res, 59, $3754-60,1999$.

[58]. SR. Ande, PR. Kommoju, S. Draxyl, M. Murkovic, P. Macheroux, S. Ghisla, E. Ferrando-May. Mechanisms of cell death induction by L-amino acid oxidase, a major component of ophidian venom. Apoptosis 2006; 11: 1439-1451.

[59]. M. Y. Ahn, B. M. Lee, and Y. S. Kim, "Characterization and cytotoxicity of L-amino acid oxidase from the venom of king cobra (Ophiophagus hannah)," International Journal of Biochemistry and Cell Biology, vol. 29, no. 6, pp. 911-919, 1997.

[60]. R. G. Stabeli, L. M. PimentaMagalhaes, H. S. Selistre-de-Araujo, and E. B. Oliveira, “Antibodies to a fragment of the Bothrops moojeni L-amino acid oxidase cross-react with snake venom components unrelated to the parent protein," Toxicon, vol. 46, no. 3, pp. 308-317, 2005. 